\title{
Lepidoptera from the Pantepui. Part V. New Lycaenidae (Theclinae: Eumaeini)
}

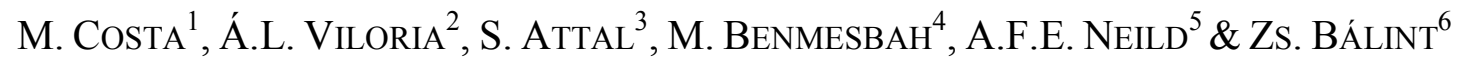 \\ ${ }^{1}$ Mauro Costa, Res. Las Cumbres, Avenida Las Acacias, La Florida, Caracas 1020-A, Venezuela. \\ Email: mauro13x50@gmail.com \\ ${ }^{2}$ Ángel L. Viloria, Centro de Ecología, Instituto Venezolano de Investigaciones Científicas (IVIC), Apartado Postal 20632, \\ Caracas 1020-A, Venezuela.Email: aviloria@ivic.gob.ve \\ ${ }^{3}$ Stéphane Attal, 5-15 Rue Olivier-Noyer, 75014 Paris, France.Email: stephane.attal@wanadoo.fr \\ ${ }^{4}$ Mohamed Benmesbah, 21 Rue des Marronniers 31830 Plaisance du Touch, France.Email: modjojojo66@hotmail.com \\ ${ }^{5}$ Andrew F.E. Neild, Courtesy Research Scientist (Lepidoptera), Florida Museum of Natural History, McGuire Center, University \\ of Florida, PO Box 112710, Gainesville,FL 32611-2710,USA.Email: andrew.neild@blueyonder.co.uk \\ ${ }^{6}$ ZZsolt Bálint, Department of Zoology, Hungarian Natural History Museum, H-1088 Budapest, Baross utca 13, Hungary. Email: \\ balint.zsolt@nhmus.hu (*corresponding author)
}

\begin{abstract}
Two new species of butterfly (Lepidoptera, Papilionoidea, Lycaenidae) from the Pantepui (Venezuela) are described; Ocaria faurei Bálint, Attal \& Costa, sp. nov. and Strymon auyana Bálint, Benmesbah \& Viloria, sp. nov. (Lycaenidae: Theclinae: Eumaeini). Notes and data are provided on the representatives of the genera Ocaria Clench, 1970 and Strymon Hübner, 1818 found in the Pantepui and in its adjacent areas in southern Venezuela with a particular focus on endemism.

Resumen. Se describen dos nuevas especies de mariposas (Lepidoptera, Papilionoidea, Lycaenidae) de diversas localidades del Pantepui (Venezuela): Ocaria faurei Bálint, Attal \& Costa, sp. nov. y Strymon auyana Bálint, Benmesbah \& Viloria, sp. nov. (Lycaenidae: Theclinae: Eumaeini). Se proveen datos y anotaciones sobre los representantes de los géneros Ocaria Clench, 1970 y Strymon Hübner, 1818 encontrados en el Pantepui y áreas adyacentes en el sur de Venezuela con particular enfoque en el endemismo.
\end{abstract}

Keywords. Akopán Tepui, Auyán Tepui, Gran Sabana, Ocaria, Ptarí Tepui, Roraima, Strymon, Wokomong, endemism.

\section{INTRODUCTION}

$\mathrm{T}$ his work is the fifth paper in the series dedicated to the Lepidoptera fauna of the Pantepui sensu Costa et al. (2014a); the first paper deals with the concept of the Pantepui, its biogeography, and its butterfly endemism; the following parts (Costa et al. 2014b, 2016 and 2017) are devoted to the description of some new taxa discovered during several expeditions carried out in the last ten years.

The type locality of the two lycaenid butterfly species we are describing here is Auyán Tepui (Figs. 1-2), which is one of the largest of the
Amazonian-Guianan shield tepuis and well known for its exceptional natural beauty, and especially for Churún Merú, better known as the Angel Falls, the highest waterfall in the world. This tepui is known to be inhabited by many endemic biological taxa, including amphibians, birds, reptiles and plants (Celsa Señaris et al. 2009), and amongst them the recently discovered nymphalid butterflies Archaeogramma claritae Costa, 2014 and Perisama tepuiensis Attal \& De Marmels, 2012.

The lycaenid fauna of Venezuela is poorly known. Special effort is necessary to get even basic knowledge about its diversity (Neild 1996: 11). 

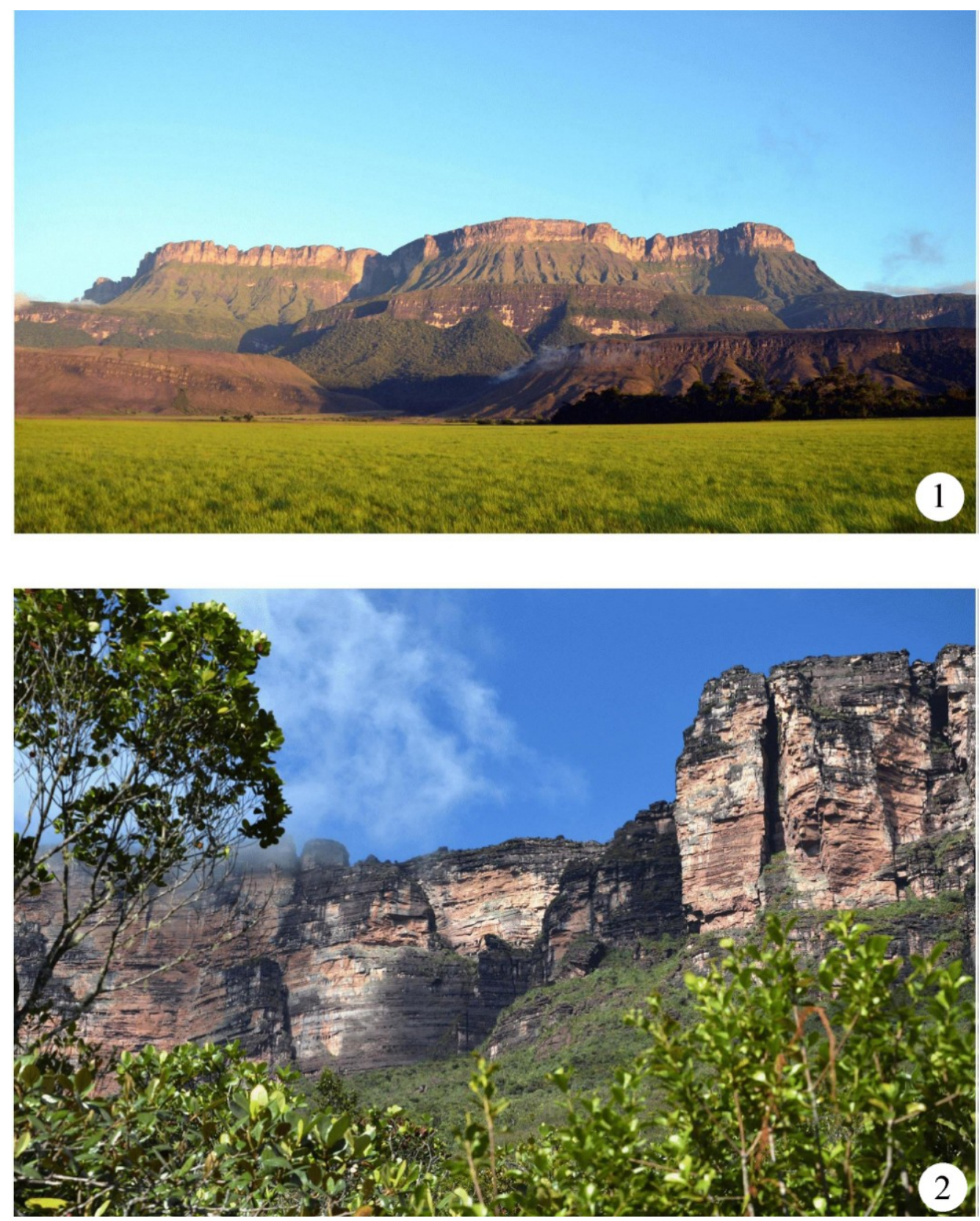

Figures 1-2. Auyán Tepui (southeastern Venezuela). 1 = Panoramic view of the southern slopes from the Río Okoiné, midway between Uruyén (a small Pemón village) and Guayaraca Camp. 2 = Habitat of Ocaria faurei and Strymon auyana spp. nov., between El Danto and El Peñón, 1700 m (0544'19"N, 62³2'14"W) (photos: Mauro Costa).

In this paper, describing two presumed endemic species from two widely distributed Panamerican genera, and discussing their congeners recorded in the Pantepui region, we hope that we contribute to a better understanding of this lesser known Venezuelan butterfly family.

\section{MATERIALS AND METHODS}

Holotypes and most paratypes are to be deposited in the Museo del Instituto de Zoología Agrícola, Facultad de Agronomía, Maracay, Venezuela (MIZA). Specimens are also deposited in the 
Hungarian Natural History Museum, Budapest, Hungary (HNHM) and in the research collection of Mauro Costa, Caracas, Venezuela (MC). Type material of previously described taxa has been consulted personally (ZsB) in the Natural History Museum, London (Bálint \& Goodger 2003, Bálint in prep.) or using photos on the Butterflies of America website (Warren et al. 2017). Material in the HNHM was used for comparison and monographs of Neotropical Lycaenidae and published papers as references in the descriptions were consulted (Draudt 1919-1920, D’Abrera 1995).

Precise geo-coordinates are given in Table 1 for taxa supposedly endemic to the Pantepui region, with the aim that exact locality documentation may support authorities to achieve habitat oriented actions for the conservation of the endemic biota.

Standard entomological techniques were used for collecting and dissecting specimens (Winter 2000). Wing measurements were collected from actual specimens using the ocular calliper of a light microscope Olympus SZX12. Three measurements are presented in $\mathrm{mm}$ in each description, for the fore and the hind wing: length of radial vein measured from vein base to terminus + length of anal vein measured from vein base to terminus + lengths between radial vein and anal vein termini. Specimens were digitalized either in the HNHM or in the home laboratory of Stéphane Attal (Paris).

After dissection, the abdomen and genitalia were placed in a plastic microvial containing glycerol and pinned to the same pin as the specimen, inventoried in the HNHM as "Bálint gen. prep. no. \#\#\#\#, and labelled accordingly. Many hairstreak lycaenid genera have uniform genitalia showing no qualitative characters helpful for interspecific discrimination, but wing coloration, wing pattern, and wing shape, as well as spatial and temporal distribution, all offer more reliable traits for taxonomic identification ( $c f$. Nicolay \& Robbins 2005, Busby et al. 2017). Therefore the genitalia of the new species are basically figured with the aim of documentation, and as a basis for an extensive future systematic revision of the genera involved

\section{RESULTS}

Family LYCAENIDAE, [Leach, 1815]

Subfamily THECLINAE, Swainson, 1831

Tribe EUMAEINI, Doubleday, 1847

\section{Genus Ocaria Clench, 1970}

\section{Ocaria faurei Bálint, Attal \& Costa, sp. nov.}

(Figures 3-12)

Material examined $(\mathrm{n}=11)$. Holotype (Figs. 34): đ̃, Venezuela, Bolívar, Auyán Tepui, El Peñón, 1850 m, 16-I-2017, M. Costa, M. Benmesbah (MIZA). Allotype (Figs. 5-6): + , idem, 03-IV2015, M. Costa (MIZA). Wing measurements in $m m$ (see "Materials and Methods"): holotype forewing $=13.5+11+12$, hindwing $=11+11+11$; allotype forewing $=12+9+11$, hindwing $=9+10+$ 9. Paratypes $(\mathrm{n}=9$, Venezuela, Bolívar): $1 \hat{\jmath}$, Roraima, Base Camp, 1900 m, 29-III-2007, M. \& C. Costa (MC); 19, Ptarí Tepui, Base Camp, 2000 m, 27-XII-2014, M. Costa (MC); 10̂, Auyán Tepui, entre El Danto y El Peñón, 1700 m, 25-III2013, M. Costa (HNHM), Bálint gen. prep. no. 1526; 10, idem, 20-I-2017, M. Costa, M. Benmesbah (MIZA); 1ㅇ, Akopán Tepui, 1400 m, 25-XII2014, M. Costa (HNHM), Bálint gen. prep. no. 1626; 10̄, Ptarí Tepui, Base Camp, 2000 m, 25XII-2014, M. Costa (MIZA), Bálint gen. prep. no. 1625; 10ิ, Auyán Tepui, El Peñón, 1850 m, 16-I2017, M. Costa, M. Benmesbah (MIZA); 10, Auyán Tepui, El Danto, 1500 m, 15-I-2017, M. Costa, M. Benmesbah (MIZA); 10ิ, idem, $1750 \mathrm{~m}$, 20-I-2017, M. Costa, M. Benmesbah (HNHM).

Classification. This species belongs to Eumaeini because it has ten forewing veins, "greyhound shaped" male genitalia lacking a juxta and a male foretarsus that is fused, used for walking, and stubby tipped (Eliot 1973). It is placed in the genus Ocaria Clench, 1970 (type species: Thecla ocrisia Hewitson, 1868) because the terminus of the aedeagus is flat and triangular-shaped with a serrated ventral keel (Clench 1970, Fig.1; see Fig. 8 ), and belongs to the O. aholiba (Hewitson, 1867) species group because the dorsal forewing scent patch fills almost the entire discal cell area (Bálint \& Costa 2012; see Fig. 7). 
Diagnosis. Within the Ocaria aholiba species group (see Bálint \& Costa 2012), O. aholiba is superficially the most similar species but $O$. faurei differs as follows: the ventral forewing surface (1) is without a conspicuous discoidal line (in $O$. aholiba the discoidal line is strongly patterned with gleaming scales), (2) the postmedial pattern consists of a dark line (in O. aholiba this line is formed by gleaming scales) and (3) the submarginal area is lighter than the more basal areas (in O. aholiba the submargin is the same colour as the medial area). The Central American Ocaria clenchi (K. Johnson, 1992) is also similar, but the forewing dorsal surface in the male of that species is completely black, and the ventral wing surface is a paler brown with pinkish and reddish postmedial-submarginal areas, and with no gleaming scales.
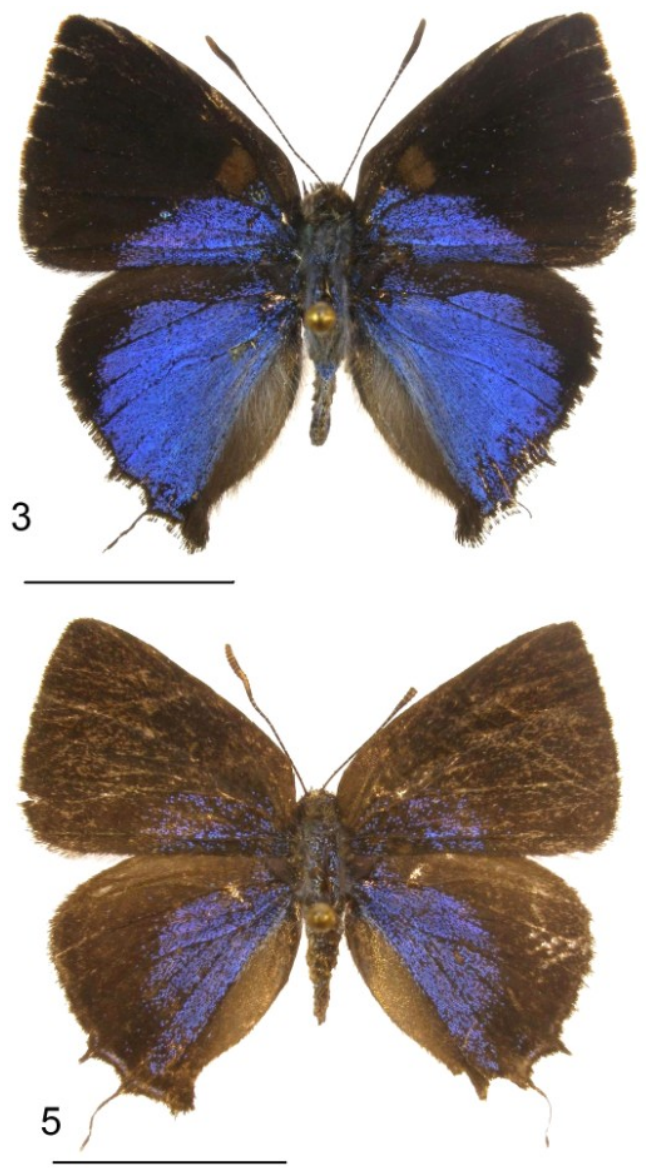

Description. Wings (Figs. 3-7). Male: Dorsal surface: forewing black with blue basal area, discal cell with scent patch coloured black distally and light brown basally, fringes brownish red. Hindwing with more extensive forewing blue coloration, black colour restricted to marginal area, widening progressively towards apex from M3, vein terminus $\mathrm{Cu} 1$ with $1 \mathrm{~mm}$ tail and $\mathrm{Cu} 2$ terminus with $5 \mathrm{~mm}$ tail, fringes black. Ventral surface: forewing basal and medial area dark brown, postmedian and submargin lighter, antemarginal area dark brown, postmedial line dark brown running continuously from vein costa to $\mathrm{Cu} 2$ not reaching the anal margin with a few irregularly scattered bright scales along its distal edge. Hindwing basal and medial areas dark brown, postmedian and submargin lighter with complex patterns, antemargin dark brown but
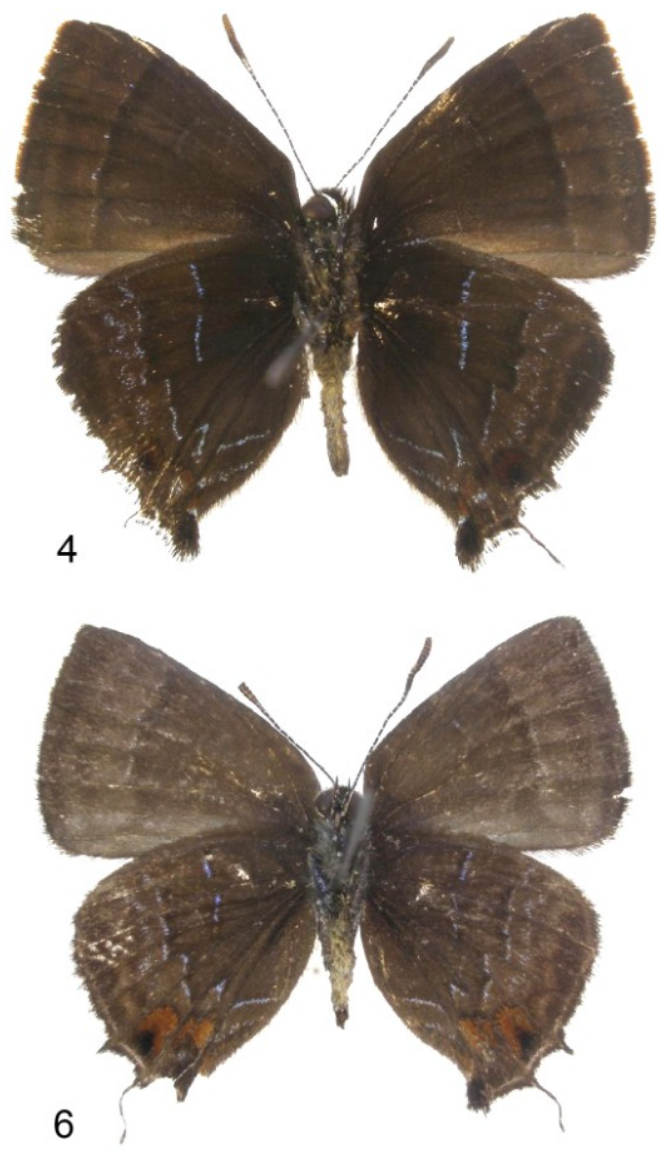

Figures 3-6. Ocaria faurei sp. nov. type material. 3-4 = holotype male ( $3=$ dorsal, $4=$ ventral). 5-6 = paratype ("allotype") female $(5=$ dorsal, $6=$ ventral). $($ scale bars $1=\mathrm{cm})$ (photos: Gergely Katona, HNHM). 

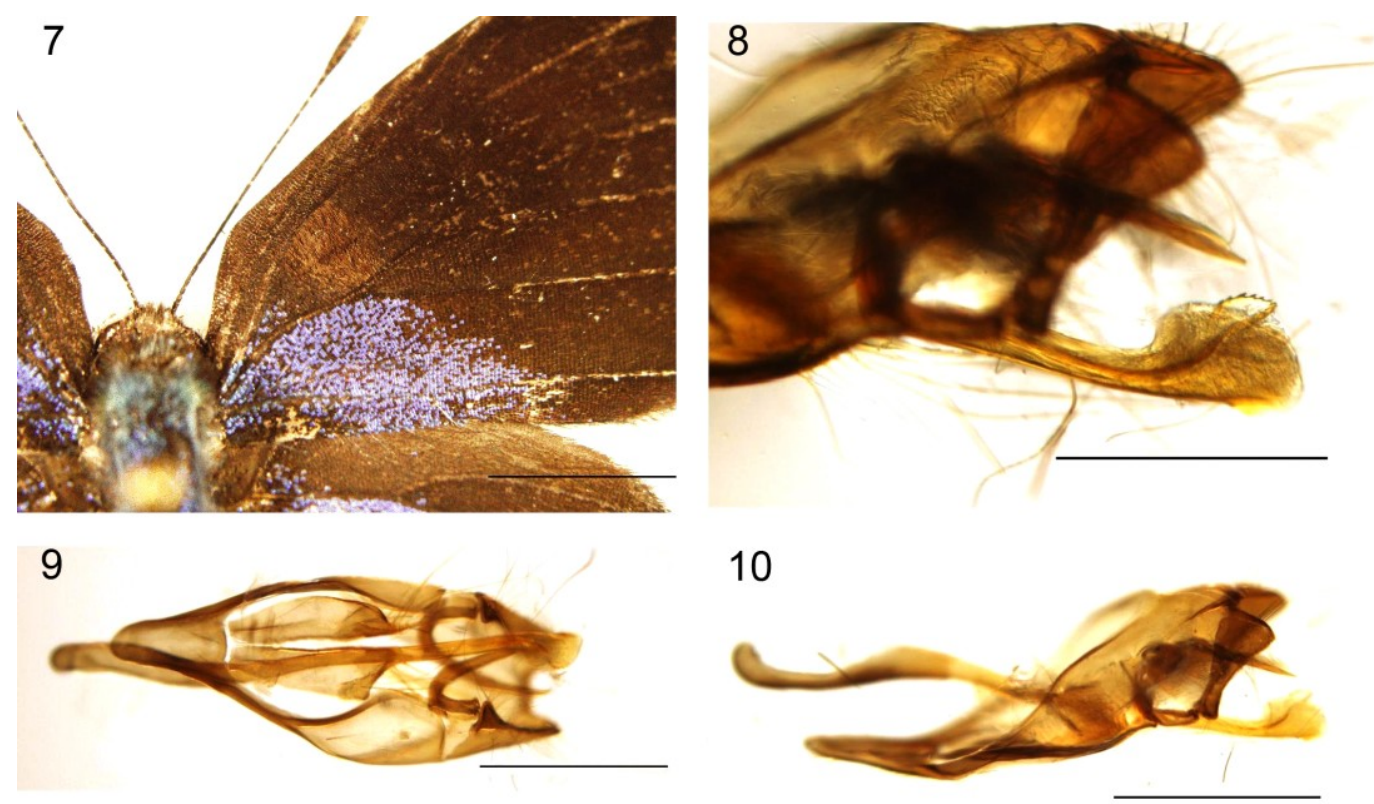

11

12
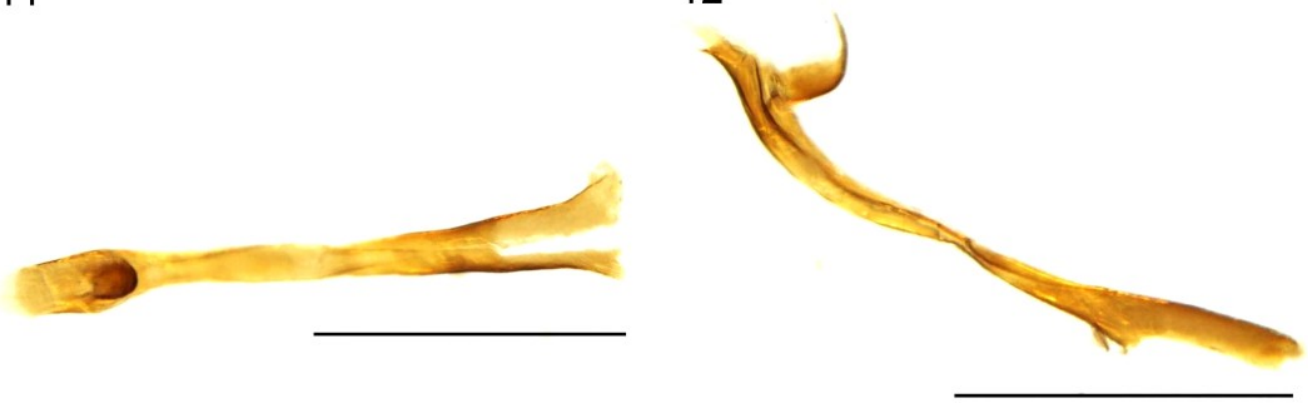

Figures 7-12. Ocaria faurei sp. nov. anatomy. 7 = holotype in dorsal view showing the head, thorax, and forewing scent patch (scale bar $=4 \mathrm{~mm}$ ), $8=$ aedeagus terminus with flat and subrectangular shaped antero-dorsal keel, $9=$ male genital capsule, ventral view, $10=$ idem, lateral view, $11=$ female ductus bursae in ventral view, $12=i d e m$, lateral view (scale bars: Fig. $8=0.6 \mathrm{~mm}$ and 9-12=1 mm) (photos: Zsolt Bálint, HNHM)

between vein $\mathrm{Cu} 1$ and inner margin patterned; submedial pattern comprised of gleaming scales running from vein $\mathrm{Sc}+\mathrm{R} 1$ to vein $\mathrm{M} 3$ broken into two sections as absent in space M1-Rs; lighter postmedial area with zigzagged pattern running from costa to inner margin formed by a dark brown line bordered distally along its edge, and by random scattered gleaming scales in the postmedial area distal to this line, running from space M1-Rs to inner margin; a large dark red antemarginal crescent-shaped patch basally enclosing a black marginal spot in $\mathrm{Cu} 2-\mathrm{Cu} 1$, another less visible antemarginal red patch in $2 \mathrm{~A}-\mathrm{Cu} 2$ with a small patch of gleaming scales distal to this, the red scaling spilling over into the adjoining tornal space; tornus black with gleaming blue scales basally. Female: similar to male, but wing surface area somewhat smaller, dorsal wing structural blue restricted to hindwing with more extensive marginal black border, ventral wing surface coloration lighter and pattern sharper, orange-red antemarginal patches in 2A-Cu2 much larger.

Body. Head (Fig. 7). Male and female: vertex and frontoclypeus covered by black hair-like scales, labial palpus with middle segment blackhaired in its lower part with some white scales mixed, terminal segment short and pointed, eyes large and hairy; antennal flagellum and club dorsally black with white ventral scaling in each segment, club reddish brown. Thorax and legs: 
covered with dark hair-like scales, excluding tibia and tarsus with normal scaling. Abdomen: dorsally and laterally gleaming blue, ventrally brown.

Genitalia (Figs. 8-12). Male with commonplace eumaeine structures without brush organ, capsule flat and bullet-shaped in lateral view, with valval and tegumenal anterior hairs, tegumen with a large pair of long and slender gnathi curved with pointed termini, posterior tegumen sclerotized, vinculum membranous but upper and lower borders sclerotized, saccus with $3 / 4$ subzonal aedeagus length, apically rounded in ventral view, valva stretched and oval-shaped in lateral view with a conspicuous apical project, lower part sclerotized, aedeagus longer than genital capsule, internal (subzonal) section short with $1 / 4$ aedeagus length and external (extrazonal) section long, posterior end upwardly open and upturned with a slightly sclerotized antero-dorsal keel dentate dorsally and somewhat subrectangular in lateral view (Figs. 8-10). Female genitalia lamella antevaginalis approximately half ductus length and composed of two long sclerotized plates divided by a membranous area, ductus simple and membraneous with sclerotized anterior parts attaching to bursa (Figs. 11-12).

Variations. The eleven specimens taken show almost no variation in size, coloration or pattern, the only notable difference is the extension of the marginal black border and the blue basal scaling (which is more extended in females). Worn specimens appear to be somewhat darker blue and the ventral pattern fades away, therefore old specimens are not easy to identify as they display only the most general eumaeine pattern.

Type locality. Southeastern Venezuela, Bolivar state, Auyán Tepui, El Peñón, 1850 m (0544' $\left.40^{\prime \prime} \mathrm{N} ; 62^{\circ} 32^{\prime 2} 7^{\prime \prime} \mathrm{W}\right)$.

Bionomics. O. faurei sp. nov. is known from several tepuis in the Gran Sabana (eastern Pantepui) such as Roraima, Auyán, Akopán and Ptarí Tepui. The Gran Sabana is an immense plateau on the Guiana Shield whose area reaches $10,800 \mathrm{~km}^{2}$ with elevations between 800 and $1200 \mathrm{~m}$. On this plateau there rise abruptly a large number of tepuis, some of which reach up to $2800 \mathrm{~m}$ eleva- tion, each isolated from its neighbours by the surrounding lower land. Each tepui is contoured by a ring of vegetation that covers the steeply inclined slopes up to where the vertical walls begin (normally around 2000-2200 m). The fact that this new species occurs on the slopes of different isolated tepuis, combined with the fact that it has never been reported from intermediate elevations $(800-1200 \mathrm{~m})$ of the Gran Sabana (much more sampled than the tepuis), suggest that $O$. faurei is most likely an endemic Pantepuian species.

The habitat of $O$. faurei is located on tepui slopes, between 1400 and $2000 \mathrm{~m}$ elevation. In these areas the slope is predominantly rocky being formed by the fall of boulders and smaller debris released by the erosion of the cliffs; the soil is therefore poor in nutrients giving rise to dense scrub vegetation (Fig. 2) with low-lying plants (2$6 \mathrm{~m}$ ) except in protected sites or along streams where small forests up to $10-12 \mathrm{~m}$ high can be found. In this environment, on sunny days, $O$. faurei adults can be seen constantly looking for nectar sources during the hottest hours of the day $(10: 00-14: 00)$; the flight is very fast and nervous, probably adapted to these areas, normally of strong winds and rich in predators (birds).

Etymology. This species is dedicated to Denis Faure (France) in gratitude for his contribution to Neotropical biodiversity research.

\section{Genus Strymon Hübner, 1818}

\section{Strymon auyana Bálint, Benmesbah \&Viloria, sp. nov.}

\section{(Figures 13-20)}

Material examined $(\mathrm{n}=5)$. Holotype (Figs. 13-14): $\hat{\jmath}$, Venezuela, Bolívar, Auyán Tepui, El Danto, 1500 m, 28-III-2015, M. Costa (MIZA), Bálint gen. prep. no. 1535. Allotype (Figs. 15-16): , Venezuela, Bolívar, Auyán Tepui, entre El Danto y El Peñón, 1750 m, 20-I-2017, M. Costa, M. Benmesbah (MIZA). Wing measurements in $\mathrm{mm}$ (see "Materials and Methods"): holotype forewing $=14+8.5+11$, hindwing $=8+9+8.5$; allotype forewing $=11+8.5+9$, hindwing $=7.5+8+9$. 

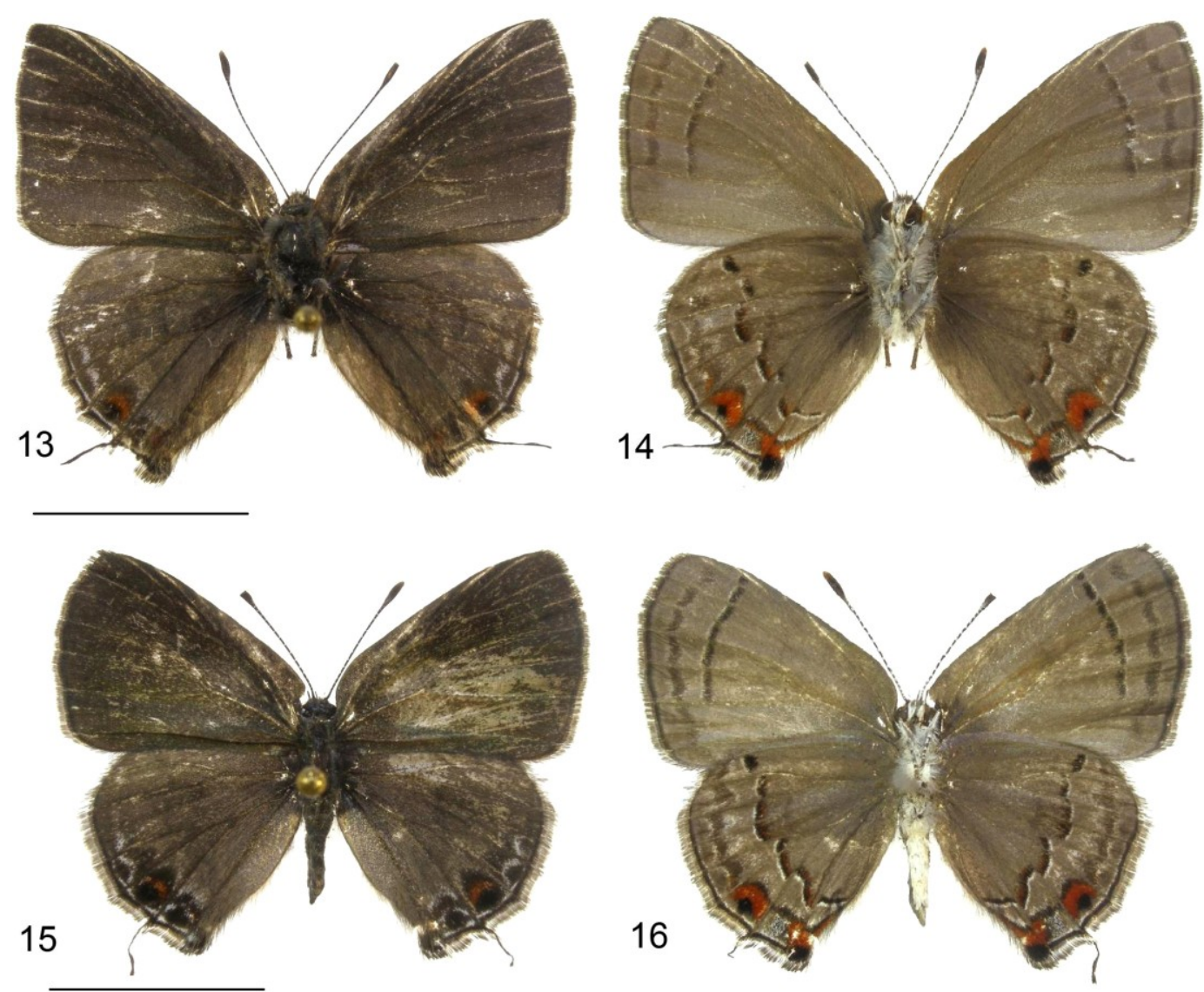

Figures 13-16. Strymon auyana sp. nov. type material. 13-14 = holotype male (abdomen removed for dissection) $(13=$ dorsal, $14=$ ventral $) .15-16=$ paratype ("allotype") female $(15=$ dorsal, $16=$ ventral $) .($ scale bars $=1 \mathrm{~cm})$ (photos: Gergely Katona, HNHM).

Paratypes $(\mathrm{n}=3$; Venezuela, Bolívar, Auyán Tepui): 1, El Danto, $1500 \mathrm{~m}, 14-01-2017$, M. Costa, M. Benmesbah (MIZA); 10̄, idem, 20-I-2017, M. Costa, M. Benmesbah (HNHM); 1 q, Auyán Tepui, entre El Danto y El Peñón, 1700 m, 04-IV2015, M. Costa (MIZA), Bálint gen. prep. no. 1536 (HNHM).

Classification. Strymon auyana sp. nov. belongs to the Eumaeini because it has ten forewing veins "greyhound shaped" male genitalia lacking a juxta, and a male foretarsus that is fused, used for walking, and stubby tipped (Eliot 1973). It belongs in the genus Strymon Hübner, 1818 (type species: Strymon melinus (Hübner, [1813])) because it has anteriorly pointing "teeth" on the dorsal surface of the valvae (Robbins \& Nicolay 2002, Figs. 1-8; see Fig. 19), and belongs to the
S. melinus species group sensu Robbins \& Nicolay (2002), because the male dorsal forewing surface lacks a scent patch and the genitalia are identical, or nearly so, to those of $S$. melinus (Robbins \& Nicolay 2002: Figs. 9, 18).

Diagnosis. Within the $S$. melinus species group of Nicolay \& Robbins (2005) Strymon auyana sp. nov. shares with $S$. cyanofusca the trait that the dorsal hindwing submarginal area is blue-scaled, but the new species has a much darker appearance both in dorsal and ventral views; the ventral surface postmedian bands are bordered basally with dark brown scales with only traces of dark orange, while other group members have reddish or red scaling basally. The new species has a distinctive appearance compared to $S$. rufofusca as well, notably the overall dark coloration, rufous scaling on 
the veins and the blue dorsal scaling along the hindwing marginal area. The obviously different S. lamasi has conspicuous white arrow-head patterns in the ventral hindwing submargin; these are barely apparent in $S$. auyana, being reduced to diffuse scales.

Description. External sexual dimorphism weak, sexes similar in size, but female hindwing shorter (see wing measurements above). Wings (Figs. 13-17). Dorsal surface: forewing greyish black with paler brown fringes (no scent patch in male); hindwing ground colour same as forewing but submargin between veins $\mathrm{M} 2$ and $\mathrm{Cu} 1$ with faint dusting of blue scales, submarginal orange
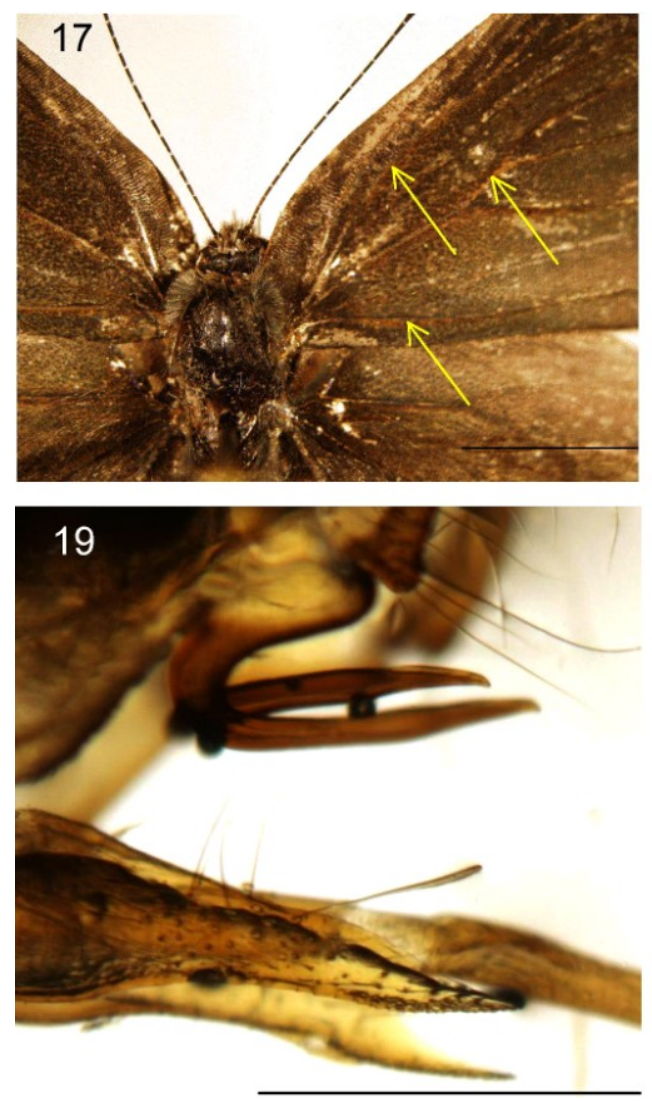

spot in space M2-M3 crescent-shaped and distally embracing a large black spot, a single narrow 3 $\mathrm{mm}$ long black tail at vein $\mathrm{Cu} 2$ terminus; margin lined with black and basally edged with a thin line of bluish scales; veins covered by rufous scales in both wings (visible under larger magnification). Ventral surface: forewing dark greyish brown, paler along the inner margin, narrow marginal black line, with fringes composed by brown and white scales, faint submarginal line of darker grey crescents, broken at each vein, from costa to vein $\mathrm{Cu} 2$, postmedial line dark brown, curving gently from costa to $\mathrm{Cu} 2$, bordered narrowly distally with greyish white, and scattered traces of orange scales basally; hindwing colours as in forewing,

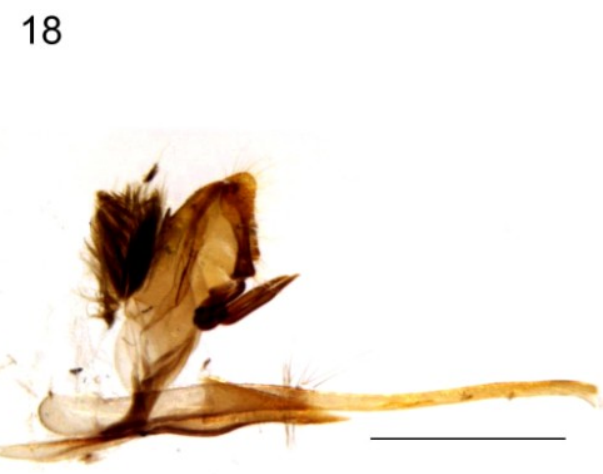

20

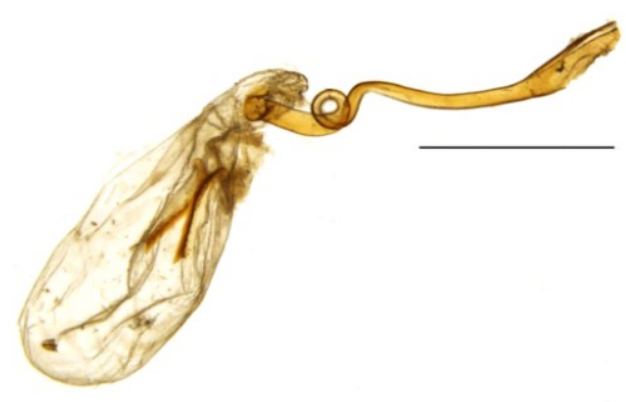

Figures 17-20. Strymon auyana sp. nov. anatomy. 17 = holotype in dorsal view showing the head, the basal and medial parts of the forewing with no scent patch; the rufous scalings along the principal veins are indicated by arrows (scale bar $=8 \mathrm{~mm}$ ). $18=$ male genital capsule, lateral view (scale bar $=1 \mathrm{~mm}$ ). $19=$ valva apex with anteriorly pointing "teeth" in lateral view (scale bar $=0.6 \mathrm{~mm}$ ). $20=$ female corpus bursae with the characteristically looped ductus in lateral view (scale bar $=1.2 \mathrm{~mm}$ ). (photos: Zsolt Bálint, HNHM). 
narrow marginal black line, basally bordered narrowly with greyish white, with paler brown fringes; a faint submarginal darker brown band from $\mathrm{Cu} 1$ to the tornus, followed distally by a scattering of whitish scales occasionally vaguely crescent shaped, postmedian line from costa to inner margin formed by interrupted dashes coloured as in forewing, a submarginal cubital black spot joined basally with a wide and vivid orange crescent lined basally with a thin dark brown crescent, a faint dusting of submarginal dark grey and whitish scales in $\mathrm{Cu} 1-\mathrm{M} 3$, black tornal spot followed basally by a large orange patch thinly lined basally with dark grey then whitish scales.

Body. Head (Fig. 17). Eyes hairy, frons grey and densely covered with longer piliform scales, labial palps white ventrally but last segment black. Thorax and cervix with a pair of brush composed by long and erecting scales. Genitalia (Figs. 18-20). Male, vinculum with a pair of brush organs, tegumen large with a small central projection; uncus large and sclerotized, falces straight with pointed apices and as long as sacculus, valva narrow and pointed in lateral view, aedeagus 2.5 times longer than valval length with apices slightly downturned, cornutus slender and acuminate (Figs. 18-19). Female, genitalia ductus bursae with simple sclerotized loop, ductus seminalis arises from unsclerotized posterior end of ductus bursae, ductus with a pair of large signa with central sclerotization and pointed caudad, as is typical for congeners (Fig. 20).

Variation. The five type specimens show little variation in size, coloration and pattern, the only notable phenomenon is the extension of the submarginal blue scaling in the dorsal hindwing surface, as the two specimens collected in 2015 seem to possess less blue scaling compared to the three specimens taken in 2017. However, a larger sample most probably would demonstrate more variation in size and coloration, as has been recorded in other Strymon species (see Nicolay \& Robbins 2005).

Type locality. Southeastern Venezuela, Bolívar state, Auyán Tepui, El Danto, 1500 m, 0543' $45^{\prime \prime N} ; 62^{\circ} 32^{\prime 2} 24^{\prime W}$ (Fig. 37).
Bionomics. Strymon auyana sp. nov. is known only from the slopes of Auyán Tepui, one of the largest of the Guiana Shield, between elevations of $1500-1750 \mathrm{~m}$. The habitat is the same as the above described $O$. faure $i$ sp. nov. and of other known Pantepuian lycaenids (Ocaria elisa Bálint \& Costa 2012, Calycopis matho (Godman \& Salvin, 1887), Cyanophrys roraimiensis Johnson \& Smith, 1993) with the peculiarity that all five known specimens have been found exclusively along streams, that is, in more protected and humid environments. The elevation of the habitat and absence from other tepuis suggests that the species is probably endemic to Auyán Tepui. Most of the endemic Pantepui butterflies are usually found on the slopes of other tepuis, but as of our current knowledge, $S$. auyana joins a very limited group of species restricted to a single tepui (Perisama tepuiensis Attal \& De Marmels and Archaeogramma claritae Costa (Costa et al. 2014b)); all three are endemic to Auyán Tepui.

Etymology. The species is named after the type locality. The species name is formed by latinising „Auyán" and treating it as a female noun in apposition.

\section{DISCUSSIONS}

\section{Notes on Ocaria species recorded in the Pantepui region}

(Figures 21-26)

In the diagnosis we have pointed to characters that help to discriminate the new species. Here, we further explore this topic. As noted earlier, the genus Ocaria sensu Robbins (2004) can be subdivided into various species groups having distinctive wing shapes, patterns and coloration (Bálint \& Costa 2012). The new species $O$. faurei belongs to the aholiba species group and in that aggregation an undescribed species from southeastern Brazil (represented by a pair deposited in the HNHM) has similar male dorsal wing surface coloration. However, the underside pattern of the Brazilian specimens is distinctive, having a conspicuous white median line crossing the forewing 
surface from the costa to the anal angle with a lighter ground colour, somewhat like $O$. aholiba. The dorsal blue coloration with brown underside ground colour, plus the reduced pattern, all make $O$. faurei somewhat reminiscent of sympatric $O$. elisa. However, these two taxa are conspicuously different in size $(O$. elisa is much larger with forewing costa length $>14 \mathrm{~mm}$ ), wing shape (the wing shape of $O$. elisa is rounder), male androconia $(O$. elisa discal cell with scent patch coloured brown distally and black basally) and fine details of the hindwing ventral postmedian pattern (in $O$. elisa the postmedian area has extensive gleaming scales). On the basis of these character differences and available site data (spanning several years and different tepuis), we consider $O$. faurei to be distinct from any of the known Ocaria species.

The genus Ocaria has more than 15 species in the Neotropical region (Robbins 2004, Bálint \& Costa 2012). In the Pantepui two supposedly endemic species have been recorded to date; the above described $O$. faurei, and $O$. elisa Bálint \& Costa, 2012. A third widely distributed species, Ocaria thales (Fabricius, 1793), has been reported from the Gran Sabana up to maximum elevations of $1100 \mathrm{~m}$ and is not a Pantepui endemic. In the following list we present our unpublished Pantepui records of the latter two species and briefly annotate them.

\section{Ocaria elisa Bálint \& Costa, 2012}

(Figures 21-24)

Material examined $(\mathrm{n}=11)$. Venezuela, Bolívar): $1 \widehat{\jmath}$, Talud Ptarí Tepui, Salto Iworé, $1400 \mathrm{~m}$, 19-XII-2014, M. Costa (HNHM); 10̄, Talud Ptarí Tepui, 2000 m, 25-XII-2014, M. Costa (MC); 1옹 Talud Ptarí Tepui, Salto Iworé, 1400 m, 19-XII2014, M. Costa (MC); 1, Talud Ptarí Tepui, 1800 m, 27-XII-2014, M. Costa (MC); 29, idem, but 2000 m (MC, HNHM); 10̄, Auyán Tepui, El Peñon, 1850 m, 16-I-2017, M. Costa/M. Benmesbah (MC); 10, idem, 21-XII-2012, M. Costa (MC); 19, Auyán Tepui, entre El Danto y El Peñón, 1750 m, 29-III-2015, M. Costa (MC); 1운
Ptarí Tepui, 1900 m, 14-XII-2015, M. Costa (MC); 1ㅇ, Talud Ptarí Tepui, Salto Iworé, 1400 m, 16-XII-2015, M. Costa (MC).

Remarks. This species was described recently from the mountains of the Sierra de Lema (Gran Sabana), at an elevation of $1400 \mathrm{~m}$ (Bálint \& Costa 2012). The additional records presented here suggest that the species occurs more frequently at higher elevations and is widespread on the slopes of other tepuis, sharing the very same habitat as $O$. faurei. As in the case of this latter species, there is no record of $O$. elisa from mid elevations $(800-1200 \mathrm{~m})$ of the well-sampled Gran Sabana, so we consider this taxon also to be endemic to the Pantepui. A female specimen of $O$. elisa has also been recorded from Mt. Wokomong (Guyana) by Steve Fratello (erroneously reported in Bálint \& Costa 2012, Figs. 13-14, from Mt. Roraima, Brazil). Mt. Wokomong is part of the Pantepui (Costa et al. 2014a: 196-198) and, in light of these new records for $O$. elisa, its presence in the Guyanan Pantepui does not seem strange. Although this record was known to us, the specimen could not be examined physically, therefore it was not listed among the paratypes by Bálint \& Costa (2012); there was also some doubt that it could be the female of an undescribed taxon of the $O$. aholiba species group illustrated in the same paper (Bálint \& Costa 2012: 308, Figs. 15-16). New evidence obtained in recent expeditions have led to the conclusion that the male represented in Figs. 15-16 from Mt. Roraima (Guyana) was indeed the above described $O$. faurei, while the female from Mt. Wokomong (Figs. 13-14) does in fact belong to O. elisa. Eumaeine hairstreak females are often difficult to associate with males (cf. Busby et al. 2017) and specimens are in need of thorough evaluation as the Mt. Wokomong female testifies.

\section{Ocaria thales (Fabricius, 1793)}

(Figures 25-26)

Material examined $(\mathrm{n}=5)$. Venezuela, Bolívar): $1{ }^{\lambda}$, entre S. Elena e Icabarú, km 21, $1000 \mathrm{~m}$, 31-XII-1985, M. Costa (MC); 10̂, idem, km 36, 

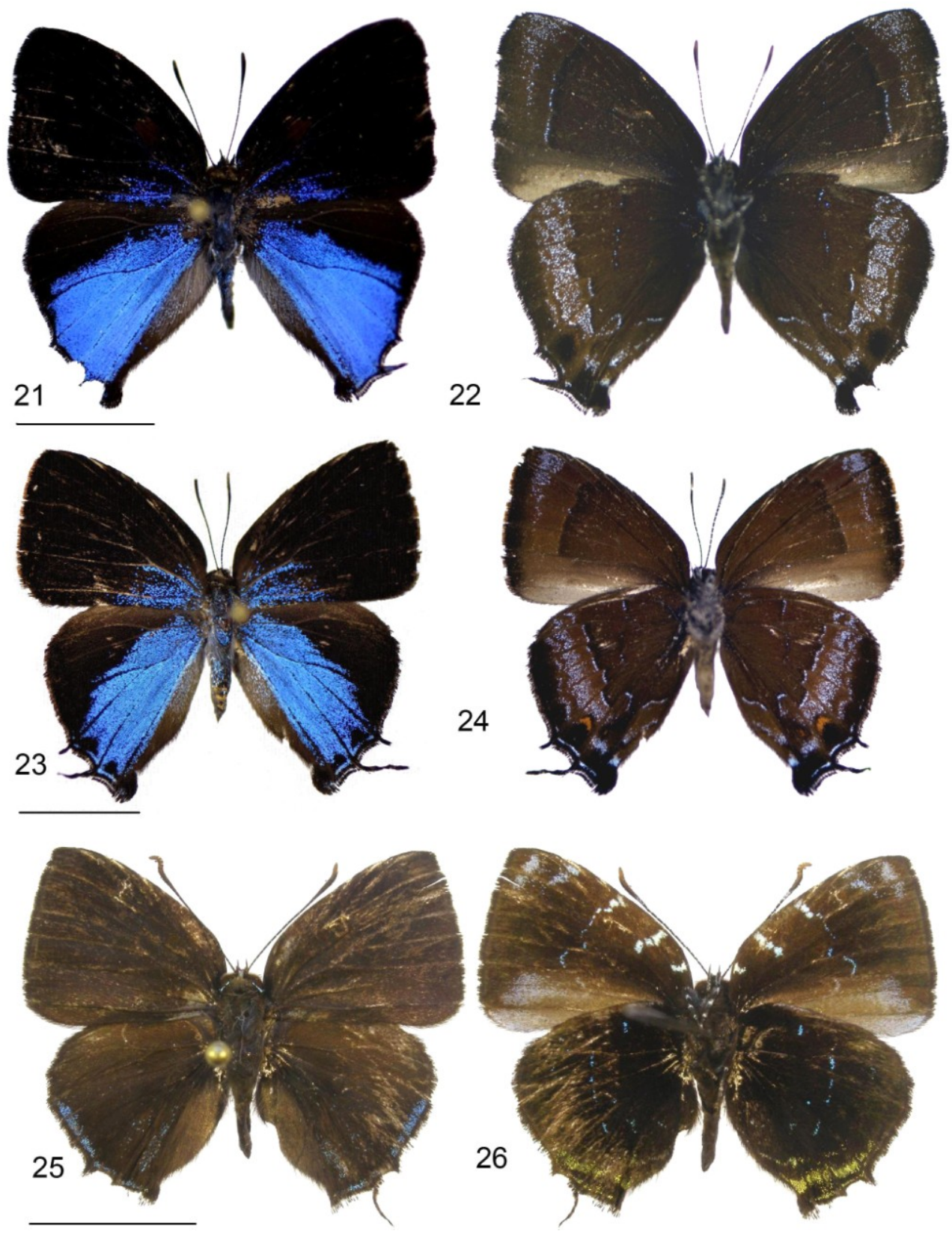

Figures 21-26. Additional Ocaria species recorded in southeastern Venezuela. 21-24 = Ocaria elisa Bálint \& Costa, 2012. 2122 = male, Ptarí Tepui, 1900 m, 14.XII.2014 (21 = dorsal, 22 = ventral). 23-24 = female, Auyán Tepui, 1750 m, 29. III.2015

(23 = dorsal, $24=$ ventral view). 25-26 = Ocaria thales (Fabricius, 1793), male, Sierra de Lema, 1100 m, 1.IV.2007, $(25=$ dorsal, $26=$ ventral $)$. (scale bars $=10 \mathrm{~mm}$; note how $O$. elisa is larger than $O$. thales $)$ (photos: Gergely Katona, HNHM).

900 m, 01-I-1986, M. Costa (MC); 1ð, Sierra de Lema, La Escalera, 1100 m, 01-IV-2007, M. Costa (HNHM); $1 \delta^{\Uparrow}$ and 19 , Talud Ptarí Tepui, vía Salto Iworé, 1000 m, 11-XII-2015, M. Costa (MC).
Remarks. This is a Panamerican species (not a Pantepui endemic) recorded from Mexico to southern Brazil, Argentina (Warren et al. 2017) and Paraguay (D'Abrera 1995: 1169); it is easy to 
identify on the basis of its distinctive wing shape, pattern and coloration.

\section{Notes on Strymon species recorded in the Pantepui region}

(Figures 27-36)

The genus Strymon has more than 50 species in the Neotropics (Nicolay \& Robbins 2005). In the Pantepui and its underlying areas six of them have been recorded. It is easy to separate these species on the basis of male wing characters, as the key below demonstrates. Hitherto undescribed endemic or unrecorded Strymon species may occur in the region (for example: S. astiocha (Prittwitz, 1865) S. istapa (Reakirt, [1867]) S. melinus Hübner, [1818], S. rufofusca (Hewitson, 1877)). If they are reported the key presented below will have to be updated.

\section{Strymon lucena (Hewitson, 1868)}

(Figures 27-28)

Material examined $(\mathrm{n}=1)$ : $1 \hat{\jmath}$, Venezuela, Bolívar, Auyán Tepui, El Peñón, 1850 m, 16-I2017 M. Costa, M. Benmesbah (MC).

Remarks. Robbins (2010: 30) comments on the nomenclatural and taxonomic problems identifying this species and its relatives. The single specimen captured matches well with the type of Thecla lucena described on the basis of material originating from Venezuela. The presence of this unique specimen of a widespread lowland Amazonian species, at such a high elevation as El Peñón in Auyán Tepui, can be attributed to straying; strong uplift currents may in fact transport butterflies to areas far from their normal habitat, as happens occasionally with the finding of solitary specimens of common lowland species on the summits of the highest tepuis, as is the case of a male specimen of Marpesia chiron (Fabricius, 1775 ) found (MC) on the plateau of Mt. Roraima at an altitude of $2750 \mathrm{~m}$ or a male specimen of Prepona claudina sardanapalus (H. Bates, 1860) found near the summit of Sororopán Tepui (2050 m) at $1900 \mathrm{~m}$.

\section{Strymon megarus (Godart, [1824])}

(Figures 29-30)

Material examined $(\mathrm{n}=8)$. Venezuela, Bolívar): 2ภ, 1q,vía Karuay-Iworé, $1050 \mathrm{~m}, 04-\mathrm{I}-$ 2012, M. Costa (MC); 10̂, vía Uruyén-Guayaraca, $1000 \mathrm{~m}, 22-\mathrm{III}-2013$, M. Costa (MC); 1ठ, Auyán Tepui, entre Uruyén y Guayaraca, 1000 m, 28-III-2013, M. Costa (MC); 10̄, Auyán Tepui, Guayaraca, 1100 m, 10-I-2017 M. Costa, M. Benmesbah (MC); 1ð̄, 1ㅇ, idem, 21-I-2017 M. Costa, M. Benmesbah (MC).

Remarks. This is a Panamerican species recorded from Mexico to southern Brazil (D'Abrera 1995: 1239 [as S. basilides Geyer], Warren et al. 2017). Robbins (2010) distinguishes three phenotypes characteristic of the Transandean, Amazonian and Atlantic areas (sensu Brown 1982), leaving open the question whether they are distinct species or geographical or clinal forms. All specimens reported from areas underlying the Pantepui match well with the Transandean phenotype.

\section{Strymon sabinus (Felder \& Felder, 1865)}

(Figures 31-32)

Material examined $(\mathrm{n}=1) \cdot 1 \hat{\jmath}$, Venezuela, Bolívar, Auyán Tepui, El Peñon, 1850 m, 03-IV2014, M. Costa (MC).

Remarks. D'Abrera (1995: 1238) indicates the distribution as Colombia to Brazil, and figures the "holotype" of T. sabinus (actually a syntype, see Bálint \& Goodger 2003) and a female from "Venezuela, Valencia". Le Crom \& Johnson (1997) recorded and figured $S$. sabinus from "Colombia, Meta, Remolinos". Robbins (2004) placed the taxa Thecla sabinus (type locality: "Bogotá") and Thecla promissa Möschler, 1883 (type locality: "Surinam") in synonymy. The holotype of $T$. promissa is a male specimen, whilst the known syntype of $T$. sabinus is a female; they represent most probably the same species correctly known as Strymon sabinus. The presence of this apparently lowland taxon on the high slopes of Auyán Tepui is unusual; however it seems to be a stray, as in the case of $S$. lucena above. 

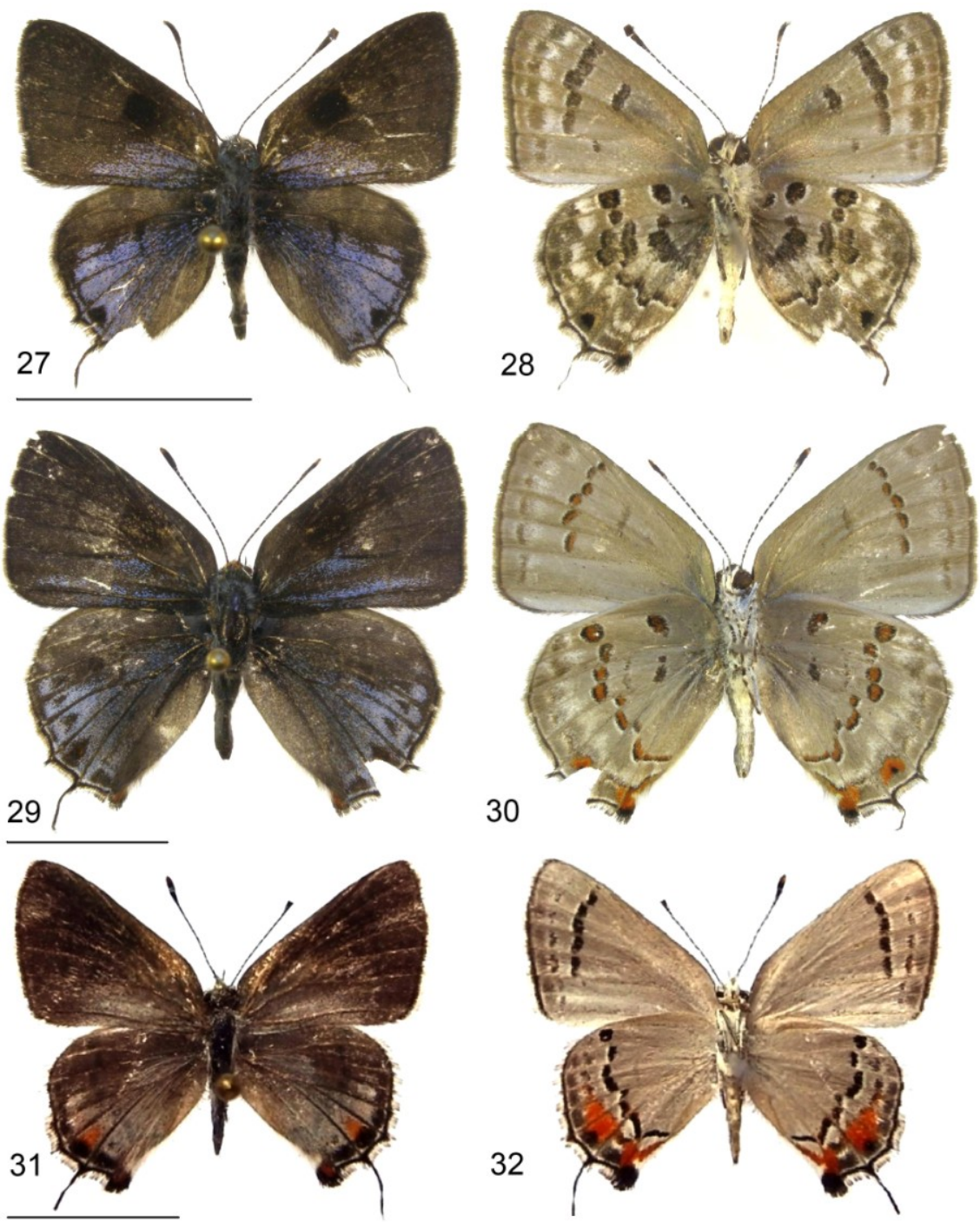

Figures 27-32. Additional Strymon species recorded in southeastern Venezuela. 27-28 = Strymon lucena (Hewitson, 1868), male, Auyán Tepui, 1850 m, 16.I.2017 (27 = dorsal, 28 = ventral). 29-30 = Strymon megarus (Godart, [1824]), male, Auyán Tepui, 1100 m, 21.I.2017 (29 = dorsal, 30 = ventral). 31-32 = Strymon sabinus (Felder \& Felder, 1865), female, Auyán Tepui, 3.IV.2014

( $31=$ dorsal, 32 = ventral). (scale bars $=1 \mathrm{~cm}$; note the respective size differences of the three species) (photos: Gergely Katona, HNHM).

\section{Strymon serapio (Godman \& Salvin, 1887)}

(Figures 33-34)

Material examined $(\mathrm{n}=2)$. Venezuela, Bolívar): 1 ก, Chimantá Massif, Akopán Tepui, Camp. Base, 2000 m, 28-XII-2013 M. Costa (MC); 1 , idem, 30-XII-2013, M. Costa (MC).

Remarks. D'Abrera (1995: 1238) indicates that the species "serapio" has a Central American distribution ("Mexico to Panama"), whilst Warren et al. (2017) note its occurrence in Texas (as a stray), and extend its range to southern Brazil. Robbins (2004) listed ten available names as junior synonyms of $S$. serapio; specimens and types of these taxa appear on the Warren et al. (2017) website (which follows Robbins 2004), indicating that (a) either there is a single species with unusually wide phenotypical plasticity or (b) there is a complex of several species. Indeed, Robbins (2010: 32) suggests that in his concept of 
S. serapio there is probably more than one species. On the basis of the material at our disposal we are unable to reach a satisfactory decision about the taxonomy of the various phenotypes. However, we remark that in light of the working hypothesis "b" the Chimantá Massif material may represent an undescribed taxon or represents an Amazonian-Guianan species. The Chimantá Massif is an impressive group of 12 tepuis whose plateau cover a total area of $616.5 \mathrm{~km}^{2}$ and, with the slopes included, this reaches almost $1000 \mathrm{~km} 2$ (Costa et al. 2014a: 196-197); the elevation of the Chimantá plateau varies between 2100 and 2650 $\mathrm{m}$. This taxon is surely a resident of the summits; the two specimens (male and female) were collected on the expedition to the plateau of Akopán $(2000 \mathrm{~m})$ in December 2013. The habitat is characterized by the vegetation of the tepuian plateau, where most plant genera and species are endemic (for example, Brocchinia Schultes, 1830,
Stegolepis Klotzsch ex Körnicke, [1872], and Bonnetia von Martius, [1826]); it is very unlikely that a lowland species can adapt to this type of environment.

\section{Strymon ziba (Hewitson, 1868)}

(Figures 35-36)

Material examined $(n=1) .19$, Venezuela, Bolívar, Sierra de Lema, La Escalera, 1450 m, 16IV-1984, M. Costa (MC).

Remarks. This is one of the most widespread American hairstreaks, a pest of Bromeliaceae (Robbins 2010). It is recorded from Mexico to southern Brazil and Argentina (Warren et al. 2017). Robbins (2010) notes that it is a common lowland species in the Neotropics. We consider this specimen to represent a stray, and do not consider $S$. ziba to belong to the Pantepui fauna.
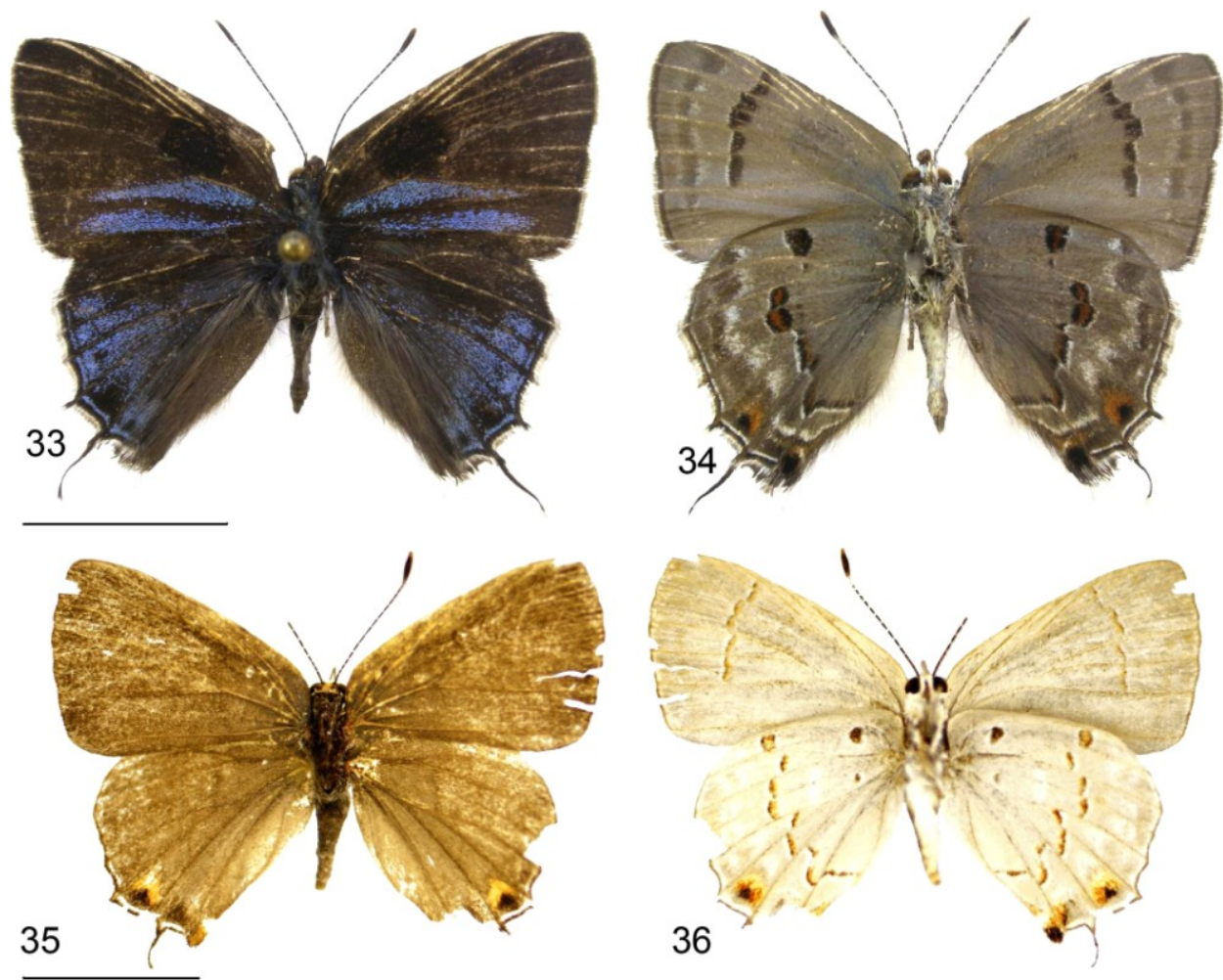

Figures 33-36. Additional Strymon species recorded in southeastern Venezuela. 33-34 = Strymon serapio (Godman \& Salvin, 1887), male, Akopán Tepui, 2000 m, 28.XII.2013 (33 = dorsal, $34=$ ventral). 35-36 = Strymon ziba (Hewitson, 1868), female, Sierra de Lema, $1450 \mathrm{~m}$, 16.IV.1984 (35 = dorsal, $36=$ ventral). (scale bars $=10 \mathrm{~mm}$; note the respective size difference of the two species) (photos: Gergely Katona, HNHM). 


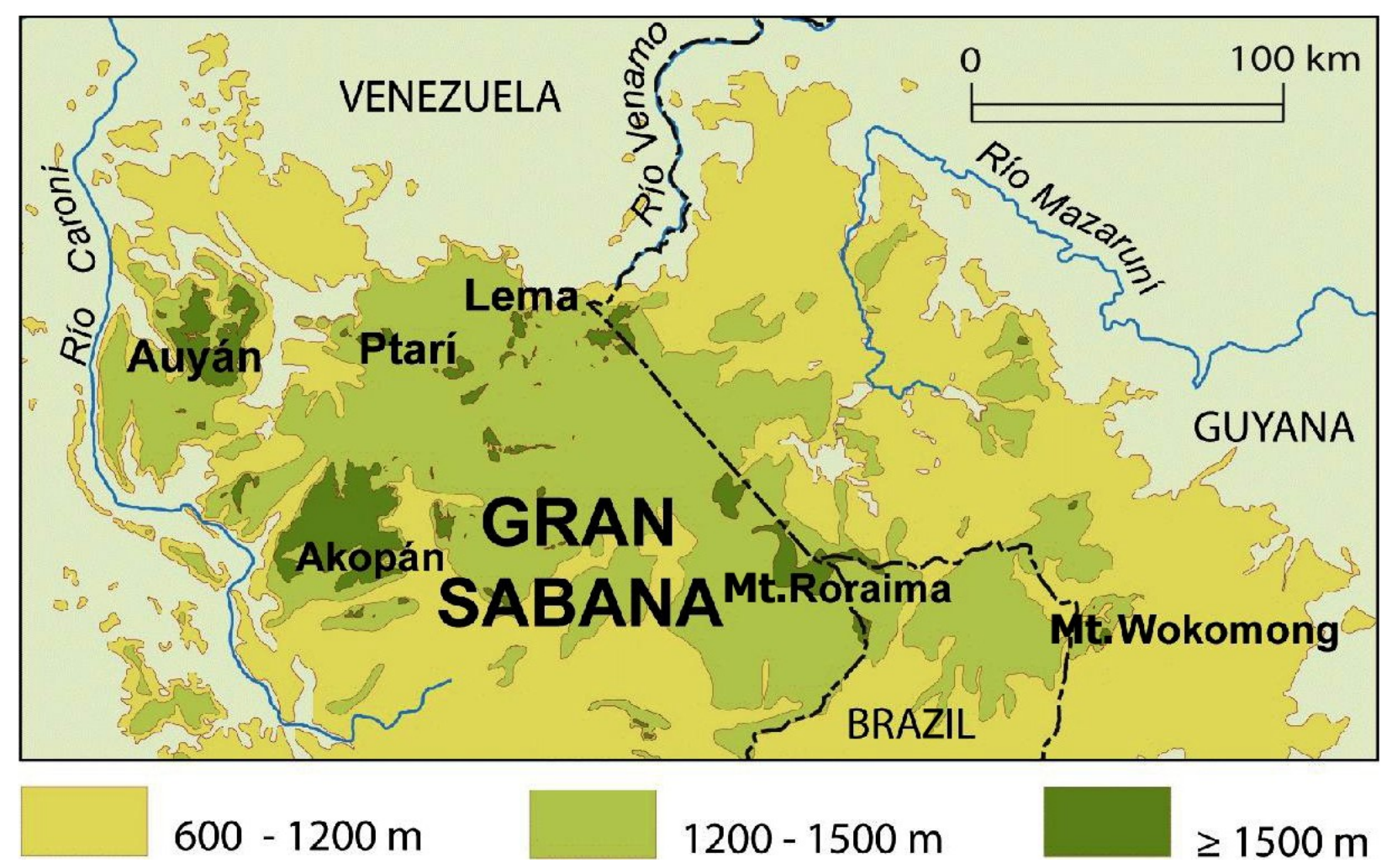

Figure 37. Geographical location of the tepuis mentioned in this paper for Ocaria and Strymon taxa (compilation: Gilles Séraphin).

Table 1. Details of localities referred to in the text and on the map (Fig. 37) for taxa endemic to the Pantepui region: Ocaria elisa, O. faurei sp. nov., Strymon auyana sp. nov. and $S$. serapio (or a possibly undescribed species).

\begin{tabular}{|c|c|c|c|}
\hline LOCALITY & COORDINATES & ELEVATION & SPECIES \\
\hline \multicolumn{4}{|l|}{ Ptarí Tepui } \\
\hline Salto Iworé & $05^{\circ} 43^{\prime} 34^{\prime \prime N} ; 61^{\circ} 48^{\prime} 36^{\prime \prime W}$ & $1400 \mathrm{~m}$ & O. elisa \\
\hline \multirow{2}{*}{$\begin{array}{l}\text { Between Punto Phelps and } \\
\text { Base Camp (Ptarí Tepui) }\end{array}$} & $05^{\circ} 45^{\prime} 32^{\prime \prime N} ; 61^{\circ} 48^{\prime} 53^{\prime \prime} \mathrm{W}$ & $1800 \mathrm{~m}$ & O. elisa \\
\hline & $05^{\circ} 45^{\prime} 41^{\prime \prime} \mathrm{N} ; 61^{\circ} 48^{\prime} 59^{\prime \prime} \mathrm{W}$ & $1900 \mathrm{~m}$ & O. elisa \\
\hline Base Camp (Ptarí Tepui) & $05^{\circ} 45^{\prime} 41^{\prime \prime} \mathrm{N} ; 61^{\circ} 48^{\prime} 49^{\prime \prime} \mathrm{W}$ & $2000 \mathrm{~m}$ & O. elisa, O. faurei \\
\hline \multicolumn{4}{|l|}{ Akopán Tepui } \\
\hline Akopán tepui slope & $05^{\circ} 12^{\prime} 34^{\prime \prime} \mathrm{N} ; 62^{\circ} 00^{\prime} 32^{\prime \prime} \mathrm{W}$ & $1400 \mathrm{~m}$ & O. faurei \\
\hline Base Camp & $05^{\circ} 11^{\prime} 38^{\prime \prime} \mathrm{N} ; 62^{\circ} 02^{\prime} 41^{\prime \prime} \mathrm{W}$ & $2000 \mathrm{~m}$ & $\begin{array}{l}\text { S. serapio (possible new } \\
\text { taxon) }\end{array}$ \\
\hline \multicolumn{4}{|l|}{ Auyán Tepui } \\
\hline El Danto & $05^{\circ} 43^{\prime} 45^{\prime \prime} \mathrm{N} ; 62^{\circ} 32^{\prime} 24^{\prime \prime} \mathrm{W}$ & $1500 \mathrm{~m}$ & S. auyana, O. faurei \\
\hline Entre El Danto y El Peñón & $05^{\circ} 44^{\prime} 19^{\prime \prime} \mathrm{N} ; 62^{\circ} 32^{\prime} 14^{\prime \prime} \mathrm{W}$ & $1700 \mathrm{~m}$ & S. auyana, O. faurei \\
\hline El Peñón & $05^{\circ} 44^{\prime} 40^{\prime \prime} \mathrm{N} ; 62^{\circ} 32^{\prime} 27^{\prime \prime} \mathrm{W}$ & $1850 \mathrm{~m}$ & O. elisa, O. faurei, \\
\hline \multicolumn{4}{|l|}{ Mt. Wokomong } \\
\hline Mt. Wokomong slopes & Not available & $1500 \mathrm{~m}$ & O. elisa \\
\hline \multicolumn{4}{|l|}{ Mt. Roraima } \\
\hline Base Camp & $05^{\circ} 08^{\prime} 52^{\prime \prime} \mathrm{N} ; 60^{\circ} 46^{\prime} 53^{\prime \prime} \mathrm{W}$ & $1900 \mathrm{~m}$ & O. faurei \\
\hline
\end{tabular}




\section{Key to the Strymon species of the Pantepui based on males}

1. Male, dorsal forewing surface without scent patch, ventral hindwing surface with submarginal spot in space Sc+R1-Rs.

- Dorsal forewing surface with scent patch, ventral hindwing surface with additional postbasal or median spot in space $\mathrm{Sc}+\mathrm{R} 1-\mathrm{Rs}$

2. Dorsal wing surface basal areas with structural blue colour on both wings, ventral wing surface ground colour light grey

\section{S. sabinus}

- Dorsal wing surface basal areas brown without structural coloration, ventral wing surface ground colour greyish dark brown . S. auyana sp. nov.

3. Hindwing ventral surface without postbasal markings......

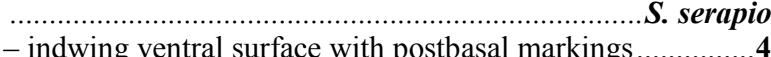

S. ziba

4. Dorsal wing surface without blue scaling

- Dorsal wing surface with blue scaling.

5. Ventral wing surface postbasal and medial pattern composed of orange and brown coloured scales with conspicuous discal spots.....

S. lucena

- Ventral wing surface postbasal and median pattern composed of red and brown scales with faint or missing discal spot

S. megarus

Acknowledgements - We thank Paolo Costa and Dulce Romero for their help and company in the recent expeditions to the Pantepui with Ricardo, Tito and Martín Chaní, from the Pemón community of Kavanayén; Boris and Nicolás Briceño from the Pemón communities of Santa Marta and Uruyén. This work would not have been possible without the support of curators and collection managers in the MIZA collection (UCV, Venezuela), whom we thank for their assistance and cooperation: Vilma Savini, José Clavijo, Jürg De Marmels, Quintín Arias, and Marco Gaiani; our gratitude also extends to Gilles Séraphin (France), author of the distribution map, and to Steve Fratello (USA) for providing important information and data about the Guianan Pantepui. And finally cordial thanks are due to Gergely Katona (HNHM) for technical assistance in the preparation of the manuscript, for digitizing specimens and preparing the plates. Zsolt Bálint was supported by the scientific grants OTKA 111741 and 115724.

\section{REFERENCES}

BÁlint, Z. \& CostA, M. (2012): Description of an Ocaria species from the Venezuelan Pantepuy [!] (Lepidoptera: Lycaenidae: Theclinae). Annales historico-naturales Musei nationalis hungarici, 104: 299-310.
BÁLINT, Z. \& GOODGER, K. (2003): The Neotropical eumaeine lycaenids of the Cajetan and Rudolf Felder collection. Part I: Review of type material of the taxa described by the Felders (Lepidoptera, Lycaenidae). Quadrifina, 6: 67-140.

BROWN, K. JR. (1982): Historical and ecological factors in the biogeography of aposematic neotropical butterflies. American Zoologist, 22(2): 453-471. doi: $10.1093 / \mathrm{icb} / 22.2 .453$

Busby C.R., FAynel C., Moser A. \& Robbins, R.K. (2017): Sympatric Diversification in the Upper Amazon. A Revision of the Eumaeine Genus Paraspiculatus (Lepidoptera: Lycaenidae). Smithsonian Contributions to Zoology 649: 1-65. doi: $10.5479 /$ si.1943-6696.649

Celsa SeÑaris, I., LEW, D. \& LASSO, C. (Eds.) (2009): Biodiversidad del parque Nacional Canaima. Bases técnicas para la conservación de la Guayana venezolana. Fundación la Salle de Ciencias Naturales y The Nature Conservancy, Caracas, 256 pp.

Costa, M., Viloria, Á.L., Huber, O., Attal, S. \& OrellanA, A.M. (2014a): Lepidoptera del Pantepui. Parte I: Endemismo y caracterización biogeográfica. Entomotropica, 28(3): 193-217.

Costa, M., Viloria, Á.L., AtTAl, S. \& OrellanA, A.M. (2014b): Lepidoptera del Pantepui. Part II. Descripción de nuevos Nymphalidae (Papilionoidea). Bulletin de la Société entomologique de France, 119(1): 39-52.

Costa, M., Viloria, Á.L., Attal, S., Neild, A.F.E., FrATEllo, S.A. \& NAKAHARA, S. (2016): Lepidoptera del Pantepui. Parte III. Nuevos Nymphalidae Cyrestinae y Satyrinae. Bulletin de la Société entomologique de France, 121(2): 179-206.

Costa, M., Viloria, Á.L., Attal, S., Neild, A.F.E., Fratello, S.A., Callaghan, C. \& Gallard, J.Y. (2017): Lepidoptera del Pantepui. Parte IV. Nuevos Riodinidae Riodininae y Pieridae Pierinae. Bulletin de la Société entomologique de France, 122(3): 269-286.

D'ABrerA, B. (1995): Butterflies of the Neotropical Region. Part VII. Lycaenidae. Victoria, Black Rock, Hill House. p. i-xi, 1098-1270.

ELIOT, J.N. (1973): The higher classification of the Lycaenidae (Lepidoptera): a tentative arrangement. Bulletin of the British Museum of Natural History (Entomology), 28(6): 373-506. doi: 10.5962/bhl.part.11171 
LE CROM, J.F. \& Johnson, K.D. (1997): Additions to the Strymon fauna of Colombia (Eumaeini, Strymonina). Revista de Theclinae colombianos, 2(16): $1-47$.

NEILD, A.F.E. (1996): The Butterflies of Venezuela. Part I: Nymphalidae I (Limenitidinae, Apaturinae, Charaxinae). A comprehensive guide to the identification of adult Nymphalidae, Papilionidae, and Pieridae. Greenwich, London, Meridian Publications. 144 pp, 32 pls., 18 Figs.

NiCOLAY, S.S. \& RoBBINS, R.K. (2005): Five new dryarea South American Strymon species (Lycaenidae: Theclinae) and their biogeographic significance. Journal of Research on the Lepidoptera, 38: 35-49.

RoBbins, R.K. \& NiCOLAY, S.S. (2002): An overview of Strymon Hübner (Lycaenidae: Theclinae: Eumaeini). Journal of the Lepidopterists' Society, 55(3): 85-100.
RobBINS, R.K. (2004): Lycaenidae. Theclinae. Tribe Eumaeini, In. LAMAS, G. (Ed.) Checklist: Part 4A. Hesperioidea - Papilionoidea. In. HEPPNER, J.B. (Ed.) Atlas of Neotropical Lepidoptera. Volume 5A. Gainesville, Association for Tropical Lepidoptera; Scientific Publishers, p. 118-137.

RoBBINS, R.K. (2010): The "upside down" systematics of hairstreak butterflies (Lycaenidae) that eat pineapple and other Bromeliaceae. Studies on neotropical Fauna and Environment, 45(1): 21-37 doi: $10.1080 / 01650521003751712$

Warren, A.D., Davis, K.J., Stangeland, E.M., PelHAM, J.P. \& GRISHIN N.V. (2017). Illustrated Lists of American Butterflies. [21-XI-2017]. Available at http://www.butterfliesofamerica.com

WINTER, W.D., JR. (2000). Basic techniques for observing and studying moths \& butterflies. Memoirs of the Lepidopterists' Society, vol. 5, $444 \mathrm{pp}$. 